504. 表面の異なる石英粒子を会喰した細胞の形態学的 变化

坂部砿之，本間克典，舆貴美子， 河合清之（学衛研）

石英表面の棈造が変化すると，単核細胞に対する毒性 が変化し，さらに動物の気管内に注入しても，同様な変 化の見られることを報告したが，本報では，細胞内に和 汀る変化の相異を，電子顕微鏡的に追求した。磨挽石英 とアルカリ咒理石英の，いずれも $0.05 \mu$ 以下の大きさ 飞そろえた粒子を，培湌ラット腹腔内単核細胞に与光， 一定時間後，その電顕像をしらべてみると，磨砕不英で は，大した変化は見られないのに反し，アルカリ処理石 英では，すみやかに形態学的変化がひき扣こされ，細胞 性障害されてゆくことがわかった。アリカり妈理石英の 細胞障害の trigger となる機序について考察してみた w。

505. 表面の異なる石英粒子の単核細胞に対する影響に ついて

輿 貴美子 (労衛研)

演者は，さきの本学会淿执いて，表面性状を異にする 二つの石英の単核細胞テトラゾリウム還元㙨構に対する 影響について報告したが，今回は，単核細胞に対する両 不英の作用機作を知る一つの方法として，細胞内物質の 移動について検討を行なった。即ら，アルカリ処理石茫 及び100時間磨砕石筷を，それぞれ粒度 $0.5 〜 2 \mu$ とし， これら石烍をラット腹腔内単核細胞と, 試歌管内に $37^{\circ} \mathrm{C}$ で作用せしめ，30,60，120 分後，細胞数を算定し，のち 遠心し，細胞と上清にわけ，各々について蛋白量，アミ ノ酸量を測定するとともに，Schmidt-Thanhauser 法 による分劃を行ない，酸溶性分劃，R NA分劃について は，オルシン反応及び紫外部吸取によりまた，DNA分 劃については，ヂフェニールアミン反応によって测定を 行なった。

現在までに得られな結果を総括すると，単核細胞をア ルカリ処理石英と作用させ，1時間後，テトラゾリウム 還元能が50\%低下する条件，即も，1×107個の単核細胞 に，石英 $800 \gamma$ を加えた条件を用いると，100時間磨砕石 英を加えた群では，これらの物買の変動は，対照群との 間に，ほとんど変化が認められない。一力，アルカリ処 理石英を加えた群に和いては，細胞内蛋白量，アミノ酸 量， R N A量，DNA量は，2 時間までに20\%以内の減 少にとどまり，細胞数の減少とほぼ平行しているが，酸
溶性分劃に示けるオルシン反忘性で最大吸収 $260 \mathrm{~m} \mu$, 最少吸取 $230 \mathrm{~m} \mu$ を示す物質（沶とらく nucleotide と 考光られる）は30分で35\%，1時間で50\%の減少が認め られた。

この物質の減少の割合は，粉末量との間に，直線関係 が存在し，からテトラゾリウム還元能を50\%阻害するに 要する石英量と，この物質を50\%減少せしめるのに要す る石英量は，等しい値を示した。本物質の詳細について は，な和検討を進めている。

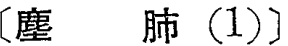

\section{6. じん肺症の肺機能}

梅田博道, 斎藤 隆, 須田吉広, 三好潤子, 内田邦彦 （東京医歯大第 2 内科） 平田重吉

(西多摩病院)

我及は，数年来，各種の職種について，じん肺法によ る肺機能検査を行なってきたのでまず，その成績を報 告し，ついで脑生理学的にも問題の多い階段䒜降試験, とくに運動指数について検討した結果を述べる。

1）数多くの検查成績をまとめると，職種による差は 明らかに認められる。同程度のX線像を示す群でも，機 能障害の程度が異なり，とくに炭鉱では，他より過剩換 気を多く認めた。また同一X線像でも，職歷年数の長い ものに，障害度の大きいものが多い。スパイロメトリー による㙨能障害の型と，階段昇降試験の成績は，必らず しも一致せず，な儎種により現われ方が異なる。

2）じえ肺法の方法は，簡単な撨気面の检査で，䏳胞 機能を推测せんとするものと考えるが，我々は，約60例 のじん肺症について，運動中和よび回復期の $\mathrm{O}_{2}$ 摂取量， $\mathrm{CO}_{2}$ 排泄量, $\mathrm{O}_{2}$ 摂取率老湘定乙, 運動時換気量, 運動 指数との関係を䧟求した。さらに安静時に㟫求した脑内 ガス分布，動脉血 $\mathrm{C} \mathrm{O}_{2}$ 分圧，運動，回復時に同時に測 定したオキシメーター・レートを加えて考察し，階段昇 降試験の成績を 4 群に分類した。すなおら， $\mathrm{O}_{2}$ 摂取量， 換気量ともに健常に此して著明に低下し， $\mathrm{O}_{2}$ 負債の大な る群，換気は增加するが酸素椇取は健常より低く $\mathrm{O}_{2}$ 負 倩のある群，著明に撸気量が增加し $\mathrm{O}_{2}$ 提取を健常に保 ら得た群，換気， $\mathrm{O}_{2}$ 摂取ともに健常な群の4 群であ る。

運動指数は必らずしも肺胞機能障害と一致しないこと を知った。

\section{7. じん肺の肺換気機能検查法の検討}


奥谷博俊，島 正吾，原田 炤， 前田 聡, 中村陽一, 奥山 静, 近藤正人，富江靖子，川上豊

（名古屋市大公衆衛生）

昭和35年度から実施されているじん肺法では，肺機能 低下が重視され，新法にもとづく肺機能検査が，ひろく 実箅されている。ところが，じん肺の管理区分の決定に あたり，職場に和㚈る学働不能度と測定值との間に，必 らずしも，一致した結果がえられず，管理上困惑するこ とが少なくない。そこで，粉じん作業者を対象とし，じ ん肺法に定められている全肺機能諸検查をこころみ，さ らにじん肺和線所見別, 性別, 年令別, 職種別, 体型別 等の観点から諸検查成績を検討してみた。

対象は, 各種産業（哭業, 機械工業, 土石採取業, 铒 業，石工業等）に従事する粉じん作業者約 1,400名であ る。検查方法は，じん肺法に示されているスパイロメ一 ターを用い，運動負荷は 2 段階段昇降法によった。

1. 各種脑機能検査成績のなかで，運動指数の異常率 忹圧倒的に高く，その判定には，性差，年令差を考慮し さらに基準値を検討してみる必要がある。

2. 最大換気量, 運動指数は職種別, 企業規模別に差 が存在し, 判定にあたり，作慈条件，作業方法，体位等 を考慮しなければならない。

3. X線上，じえ肺の進展にとるなら肺機能低下は， $\mathrm{PR}_{1} ， \mathrm{PR}_{2}$ では，核とえどみられず， $\mathrm{PR}_{3}$ にいたっ て,ようやく明らかになる。

508. じん肺及びじん肺結核症の肺機能

—じん肺法による心肺機能と肺内ガス 混合及び肺拡散ガスとの関係—

定方正一，篔田健一，春原瀷正， 湾辺登志男（珪肪労災病院外科） 游佐津根雄

(東北大麻醉)

阿部 彰 (労研)

じん然症に拉いてい，病像が複雑であるので，その結 果として招来される肺機能の損失も種々である。即ち， 脑機能测定上，肺換気面についての検查のみでは不充分 で, 肺内ガス混合, 脑拡散能力等についても, 測定が行 なわれて，綜合判定が下される必要がある所以である。

昭和35年に制定されたじん肺法に基く，心肺機能検查 も，この点についての考慮がかなりはらわれていると考 えられる。しかし, 前述の綜合的判定は, 実施上の問題 として, 肺内ガス混合, 胡拡散能力に関する測定の点で かなり困難であるので，運動負荷法によって，この欠点
が補われるよらに意図されている。

演者らは，以上の見地から，じん肺法に基く心肺機能 検查と肺内ガス混合, 肺搪散能力の浿定を行ならことに よって，いかなる点に問題があり，いかなる点に考慮を はららべきであるか検討しようとした。

被検者は，当院に入院加療した30例のじん脑及びじん 肺結核患者で，まず，じん肺法に基くし肺機能検査を行 ない，つぎに窒素計により，uniformity index を求め て, 肺内ガス混合を吟味し, 最後に 1 回酸素呼吸法によ る肺桩散能力を測定した。

その結果は，各测定值の諲価がほぼ平行する症例が多 かったが，他方，測定值の試価が必らずしも平行しない 症例もありなかでも，胡拡散能力の検查が重要視され なければならない症例のあることが知られた。以上の成 績について詳述する。

\section{9. けい肺患者の運動負荷心電図について}

上杉憲和, 佐藤守雄, 阿部達需 （日本鈆業中央綜合病院）

けい肺が，心藏機能，とくに冠循環面に和よばす影響 を知るため，当病院に督いて，入院和よび外来骖療中の 36才より73才までの，壮肺15例，南よび，けい胡結核 20 例，計 35 例，ならびに肺疾患を有しない42才より64才 までの15例について，2階段試験による運動負街を就こ ない，運動負荷前後の心電図所見，㤩よび胸部レ線像と の関係について，比較検討した。

運動傎荷前後の心拍数の增加は, 刘照群之症例之の間 に大差はなかったが，運動負荷前の心担数に恢復するま での時間! ，対照より長い例が多かった。

運動負衔後の心電図所見を, Master の基準により， 運動負荷試験陽性および陰性，さらに，その中間を疑晹 性とすると，対照群では15例中，陽性2例 (13.3\%) で あり，症例では35例中，陽性12例 $(34.3 \%)$ ，疑陽性 7 例 (20.0\%) であり，対照群に比較して，陽性出現率が高 かった。

胸部レ線像との関係を，忛肺基政病型別に双ると， 陽性例は $1 \mathrm{P} よ 2 \mathrm{P} ， 3 \mathrm{P}$ 火多く，立た病紧の大きさ 別にみると，陰影の大きい群㑥性例が多かった。を た，けい脑に結核の合併したものに，陽性例が多い傾问 が斥られた。

換気機能と運動負荷試駼の間には，一定の関倸は灭ら れなかったが，1秒率和よび肺活量の減少しているもの では，陽性例が多かった。

運動負荷前後の心電図所見では，対照群にくらべ，症 